\title{
Fleet Dynamic Analysis of the Taiwan Offshore Trawl Fishery: an Application of the Sea Surface Temperature Measures
}

\author{
Chin-Hwa Sun \\ Associate Professors, Institute of Fisheries Economics, National Taiwan Ocean University, Taiwan, R.O.C \\ Fu-Sung Chiang \\ Associate Professors, Institute of Fisheries Economics, National Taiwan Ocean University, Taiwan, R.O.C
}

Follow this and additional works at: https://jmstt.ntou.edu.tw/journal

Part of the Aquaculture and Fisheries Commons

\section{Recommended Citation}

Sun, Chin-Hwa and Chiang, Fu-Sung (2009) "Fleet Dynamic Analysis of the Taiwan Offshore Trawl Fishery: an Application of the Sea Surface Temperature Measures," Journal of Marine Science and Technology. Vol. 7: Iss. 2, Article 5.

DOI: $10.51400 / 2709-6998.2528$

Available at: https://jmstt.ntou.edu.tw/journal/vol7/iss2/5

This Research Article is brought to you for free and open access by Journal of Marine Science and Technology. It has been accepted for inclusion in Journal of Marine Science and Technology by an authorized editor of Journal of Marine Science and Technology. 


\section{Fleet Dynamic Analysis of the Taiwan Offshore Trawl Fishery: an Application of the Sea Surface Temperature Measures}

\section{Acknowledgements}

The authors thank anonymous reviewers for valuable comments on earlier drafts of this paper. This research was supported in part by the National Science Council (NSC), NSC 86-2415-H-019-003 and the Council of Agriculture (COA), 87-AC-2.2-F-01-3.12, Taiwan, Republic of China. The views expressed in this paper are those of the authors and are not be attributed to NSC or COA. 


\title{
FLEET DYNAMIC ANALYSIS OF THE TAIWAN OFFSHORE TRAWL FISHERY: AN APPLICATION OF THE SEA SURFACE TEMPERATURE MEASURES
}

\author{
Chin-Hwa Sun* and Fu-Sung Chiang*
}

Keywords: Trawl fisheries, Fleet dynamics, Sea surface temperature (SST), Wilcoxon sign test, Fisheries management.

\section{ABSTRACT}

The overall goal of this paper is to provide important information documenting and analyzing Taiwan's trawl fishing fleet activities in the northeastern of Taiwan. Seasonal SST data are used to analyze different seasonal fishing patterns and the density of fleet dynamics of offshore trawl fleet is used to identify five distinct fishing areas (A, $\mathrm{B}, \mathrm{C}, \mathrm{D}$, and E) in the northeastern of Taiwan. A Wilcoxon sign test is used to examine the variability in the percent of days spent in each fishing area from 1993 to 1996 . Results show that a significant portion of trawl vessels have shifted from the most important fishing area $\mathrm{C}$ to other areas during 1995 and 1996. Fishing area C may not be yielding sufficient harvests to warrant previous fishing levels, something that could be caused by stock depletion, which is more pronounced in area $\mathrm{C}$ than that in other areas. It is of interest to continue monitoring whether or not the fleet movement dynamics in area $\mathrm{C}$ will be influenced by the "Sino-Japan Co-Management Zone, " which was declared by Mainland China and Japan in 1997. Continuing updating database and further research are desirable in the future.

\section{MOTIVATION}

Modern history of fisheries regulation took on global dimensions with the 3rd United Nations Convention on the Law of the Sea (UNCLOS III) in 1982, which become international law and the legal framework of fisheries management after at least sixty nations signed it. At this convention, a landmark decision was reached when participating countries agreed to support the 200mile Exclusive Economic Zones (EEZs) and have a substantial redistributive effect by turning historically common property resources right to coastal nations

Paper Received June 7, 1999. Revised September 17, 1999. Accepted October 25, 1999. Author for Correspondence: Fu-Sung Chiang.

*Associate Professors, Institute of Fisheries Economics, National Taiwan Ocean University, Taiwan, R.O.C.
(Cunningham, Dunn, and Whitmarsh [1]). Through the declaration of Cancun, Mexico, the 1992 International Conference on Responsible Fishing further address the need and recommendation to international organization such as United Nations for regulating responsible fishing practices.

Following the United Nations Conference on the Environment and Development (UNCED) in 1992, Agenda 21 was passed. Agenda 21 further assigns the states ${ }^{1}$ jurisdiction, and thus effective control, over the authorization of fishing vessels, and makes it the states' responsibility to ensure that the conservation and management measures taken are effective and in accordance with international law and the International Code of Conduct for Responsible Fishing (International Coalition of Fisheries Association [2]). The Technical Consultation on the Code of Conduct for Responsible Fishing in 1994 has explicitly addressed the issue of Guidelines for the Responsible Management of Fisheries and the framework for data gathering and fish stock assessment:

"an appropriate sequence of data collection and surveys, information analysis, development of precautionary and risk-averse management options, consultation and review of these options with interested parties, and finally decision making, will need to be set up. This will have to follow a history of the resource and the seasonal operation of the fleets. Such a cyclical, annual or multiannual

\footnotetext{
${ }^{1}$ The Code is global in scope, and is directed toward members and non-members of FAO fishing entities, sub-regional, regional and global organizations, and all persons, having interest in the conservation and management of fisheries resource. The Code provides principles and standards application in offshore waters and on the high seas, as well as those of land-locked and semi enclosed seas and international lakes and rivers (Technical Consultation on the Code of Conduct for Responsible Fishing, 1994).
} 


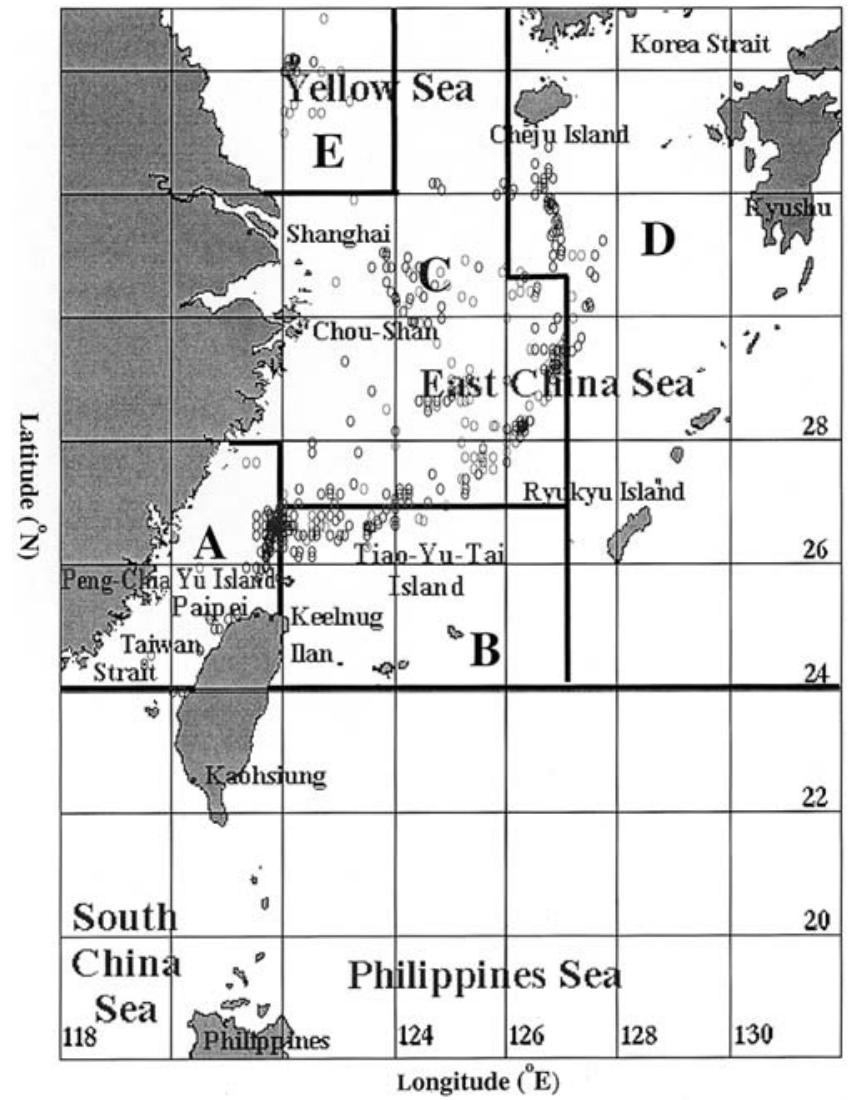

Fig. 1. The scatter diagram of the vesel movements for one representative fishing vessel in the northeastern fishing grounds of Taiwan (Jan. 1993 to Oct. 1996).

sequence of events will need to incorporate feedback and quality control loops between the components of the system."

In accordance with global trends in fisheries management, the offshore fishing industry in Taiwan is trying to meet the challenge of designing a successful management system that will help to conserve fisheries resources while allowing for the development of a dynamic and economically sustainable offshore fisheries industry. In terms of both quantity and value of offshore fisheries in Taiwan, the offshore trawl fishery has been the most important contributor to the offshore fisheries in Taiwan since 1970. However, based on Sun's [3] study which evaluated alternative offshore fisheries management polices for Taiwan, overfishing has occurred since 1973, implying the resource is clearly being depleted since harvest levels exceed estimates of maximum sustainable yield. The number of offshore fishing vessels needs to be further reduced and a better management policy which can fully monitoring the fleet movement dynamics are needed to prevent a further deterioration of the offshore fisheries resource.
In order to design a successful fisheries management policy and to enforce responsible fishing practices for trawl vessels operated in the East China Sea, it is necessary for the government to investigate the resource abundance in various fishing areas by analyzing the behavior of fishermen which we call the trawl vessel movement dynamics. The fleet movement dynamics are considered to be the fishermen's optimal timing pattern to fish under different oceanographic conditions, which reflect the resource abundance in various fishing areas and also the decisions made by fishermen in the past. No research to date has focused on analyzing trawl vessel movement dynamics in the East China Sea. This study looks at the movement dynamics of the offshore trawl fleet and integrates this information with sea surface temperature measurements for recent years. The findings should help to identify potential fisheries management options.

In addition, this study provides important information documenting Taiwan's trawl fishing fleet activities in the East China Sea, which in 1997 was declared by Mainland China and Japan as the "Sino-Japan CoManagement Zone." According to the fisheries law of Taiwan, fishing vessels over 100 tonnes are required to report their location to the Fisheries Radio Station twice daily. Presenting evidence of these records here proves that Taiwanese trawl vessels have traditionally been fishing in the East China Sea and that Taiwan has jurisdictional claim over access to these fishing grounds.

\section{TAIWAN'S TRAWL FISHERIES IN THE EAST CHINA SEA}

Taiwan's trawl fisheries operate primarily in two major fishing grounds, one to the northeast and the other to the southwest of Taiwan. Both areas are shown in Figure 1. The offshore trawl fishing ground to the northeast of Taiwan, which covers most of the East China Sea, is the most traditional fishing ground, and accounts for about half of the total offshore trawl harvest in Taiwan. According to the Taiwanese Fisheries Yearbook, the 1997 offshore trawl fisheries harvest measured 74,542 metric tonnes and was valued at NT\$6, $252,609^{2}$. The trawl fishery thus accounts for $30 \%$ of total offshore fisheries production and $37 \%$ of offshore fisheries production value, respectively.

Trawl fishing vessels operating in the northeastern fishing ground are mostly below 200 tonnes in size and are almost all registered in three major northeastern districts of Keelung, Ilan Hsien and Taipei Hsien. Chiang

\footnotetext{
2 The exchange rate was about 32.5 NT dollars to one U.S. dollar in 1997.
} 
and Sun [4] indicate that trawl vessels in the 50-100 and 100-200 tonne categories have made up almost $95 \%$ of the fishing fleet since 1983. In addition, the age distribution of the northeastern trawl fleet shows that in 1995 more than $60 \%$ of the trawl vessels were over 11 years old.

A typical trawl fish harvest is a combination of many species. Shrimp is still the major target species for Taiwan's northeastern trawl fisheries, not only because of a deterioration of groundfish stock in the East China Sea, but also because the price for shrimp is higher. A brief description of the biology of shrimp in the East China Sea is given in Wu [5]. A discussion about fishing grounds, fishing seasons, fishing gears, and mesh size, etc., can be found in Liu and Kuo [6]; Young, et al. [7]; Chow, Chen and Huang [8]; Chow and Huang [9]; Huang and Chow [10, 11, and 12].

In order to understand the movement dynamics of the offshore trawl fishing fleet, this study collected information on the choice of fishing location and tried to analyze fishermen's individual choices systematically. The sources of data used in this study include:

1. The primary movement dynamics data of individual boats which were extracted from daily logbooks kept by the Fisheries Radio Station, Keelung and Kaohsiung Fisheries Association since 1993. In 1996, there were a total of 270 vessels registered with the Fisheries Radio Station in Keelung.

2. The satellite thermal images are from "NOAA Satellite SST Imageries Database for East China Sea," Remote Sensing Lab., Department of Fisheries Information, Taiwan Fisheries Research Institute [13]. Their URL is: http://www.tfrin.gov.tw/D-FI/lab.satrs/ service/keepsst/index.html

\section{LITERATURE REVIEW AND METHDOLOGY}

Given the heterogeneous nature of the fishing fleet and the complex behavior of vessel dynamics, this study assumes that each fisherman will maximize the boat's per trip profit according to the resource abundance throughout the season. Fishermen's choice of fishing location reflects their best assessment of the relative economic cost and revenue conditions. Hence, fishermen's switching behavior or the dynamics of fleet movement is specified as a switching function between the relative revenue and cost conditions of each fishing location (Hilborn and Ledbetter [14]; Bochstael and Opaluch [15]; and Hilborn [16]).

Even though harvest uncertainty influences fishermen's commercial fishing behavior, Anderson [17] claims that individual differences in experience and management skills play an important role in determining the economic performance of each boat. Hilborn and Ledbetter [14] and Hilborn [16] show that in order to understand the movement dynamics of the British Columbia salmon purse-seine fleet, it is necessary to gather information about the revenue and cost associated with each trip before analyzing the individual fisherman's economic behavior.

Bochstael and Opaluch [15] were first to use a discrete choice function to model the supply response of a New England fishing firm under uncertainty. Eales and Wilen [18] examined fishermen's choice of fishing area using a multiple choice logit model to explain behavior. Their results suggest that fishermen do account for economic factors in a manner consistent with economic choice theories. Ward and Sutinen [19] further extended the study of fishermen behavior by using a McFadden's multinomial logit model to analyze vessel entry-exit decisions in the Gulf of Mexico shrimp fishery.

This study analyzes the fleet dynamics of trawl vessels over 100 tonnes by examining the variability in the location concentration. By utilizing a Wilcoxon sign test (Canavors [20], pp. 536-37) on the probability of individual trawl fishing vessels in different fishing grounds, the movement dynamics of the trawl fishing fleet is examined as the fishermen's optimal timing pattern to fish under the currently open-access condition. In brief, the sign test is based on the signs of the differences between paired observations of two random variables $X$ and $Y$. Let $\left(X_{1}, Y_{1}\right),\left(X_{2}, Y_{2}\right), .,\left(X_{n}, Y_{n}\right)$ be $n$ paired sample observations from the distributions of $X$ and $Y$, where the distributions are assumed to be continuous. Often there is a natural relationship between $X$ and $Y$, and thus $X$ and $Y$ need not be independent. For each pair in which $X$ exceeds $Y$ a plus sign (+) is recorded; otherwise the sign is negative (-). Since the distributions of $X$ and $Y$ are assumed to be continuous, the probability of $X_{i}=Y_{i}$ is zero. Let the probability that $X$ exceeds $Y$ be $p$. If $X$ and $Y$ are identically distributed, then $\mathrm{p}$ must be 0.5 . It must be noted, however, that $p$ can be 0.5 even when $X$ and $Y$ are not identically distributed. In essence, therefore, the null hypothesis for the sign test is $H_{0}: p=0.5$, tested against either a two-sided or a one-sided alternative hypothesis, depending on the wishes of the investigator. Notice that if $H_{0}$ is true, we would expect about half of the $n$ pairs to have + signs.

The statistic for the sign test, denoted by $s$, is the number of + signs among the $n$ pairs. Since under $H_{0}$ each pair constitutes an independent trial with a probability of a + sign of 0.5 , the binomial distribution is used to determine critical regions of size for type I error, i.e., $\mathrm{s} \sim \mathrm{b}\left(n, \frac{1}{2}\right)$. When the sample is big enough or $[n p \geq$ 5] and $[n(1-p) \geq 5]$, then the standard normal distribution statistic $(Z)$ is defined as follows: 


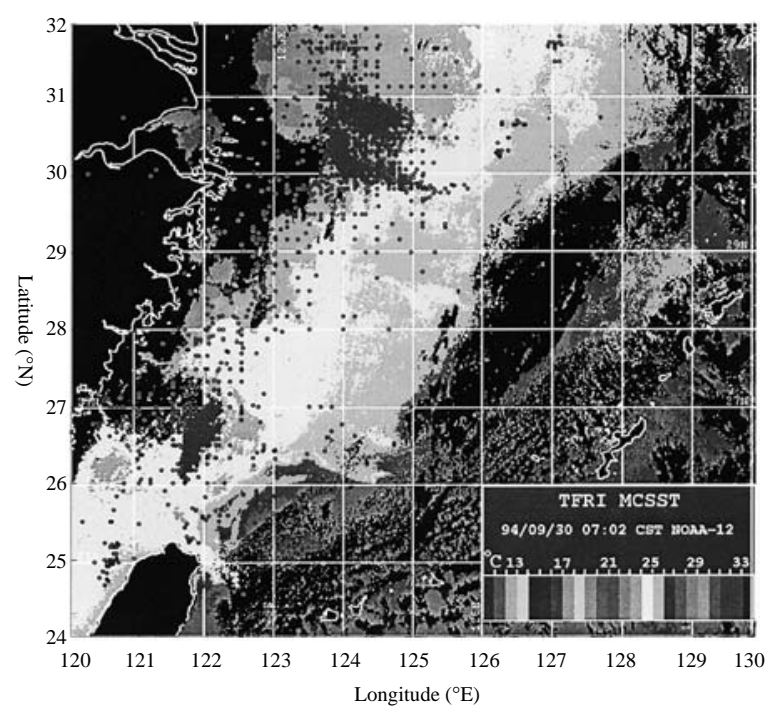

Fig. 2. The scatter diagram of Taiwan trawl vessel movements from Sept. 1 to Nov. 30, 1994 and the NOAA-12 satellite image of sea surface temperature in the East China Sea, Sept. 30, 1994.

Source: Kourshio-East China Sea Shelf Exchange Processes (KEEPII) Study, 1996, JGOFS committee located in Taipei, Taiwan, R.O. C. under the National IGBP committee, and the KEEP-II program under the National Science Council. (http://keep.oc.ntu.edu.tw/ JGOFS/).

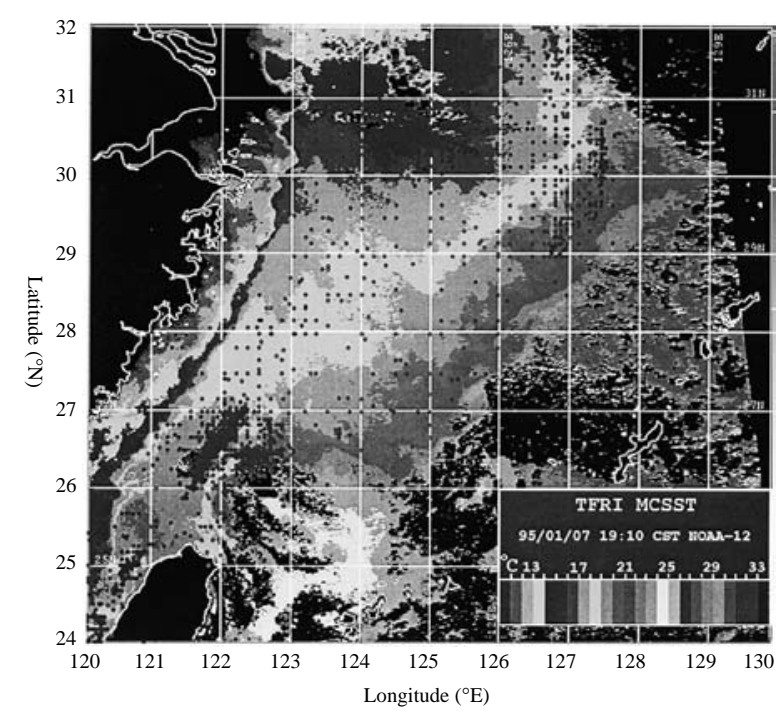

Fig. 3. The scatter diagram of Taiwan trawl vessel movements from Dec. 1 to Feb. 28, 1995 and the NOAA-12 satellite image of sea surface temperature in the East China Sea, Jan. 7, 1995.

$Z=\frac{X-\mu_{s}}{\sigma_{s}}$

where $\mu_{s}=n p$, and $\sigma_{s}=\sqrt{n p(1-p)}$

When ties occur in the application of the sign test, the recommended procedure is to ignore them and use the

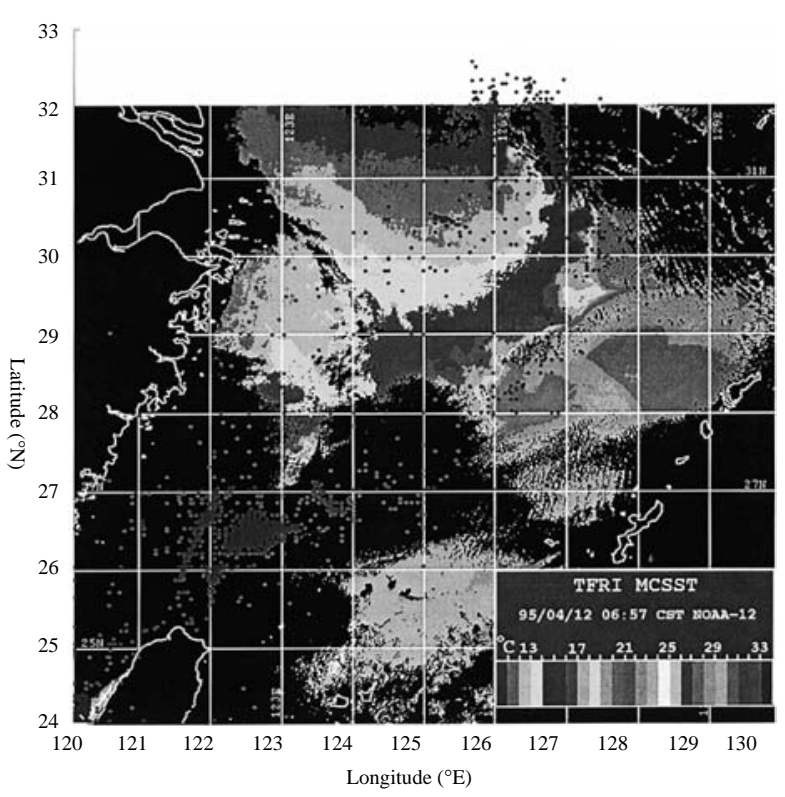

Fig. 4. The scatter diagram of Taiwan trawl vessel movements from Mar. 1 to Apr. 30, 1995 and the NOAA-12 satellite image of sea surface temperature in the East China Sea, Apr. 12, 1995.

sign test only for those pairs in which there are no ties.

\section{ANALYSIS OF SEASONAL FLEET MOVEMENT DYNAMICS, INTEGRATING SEASONAL SEA SURFACE TEMPERATURE MEASURES}

The NOAA-12 satellite images of sea surface temperature (SST) in the East China Sea, which are provided by "Kuroshio-East China Sea Shelf Exchange Processes (KEEP-I) Study" (JGOFS, 1996) from September 1994 to August 1995, are shown for various monthly periods in Figures 2, 3, 4, 5, and 6, respectively. Note that the color version of these figures is available from the authors. Numerous studies document how SST and water mass affect fishing ground dynamics, such as migration, reproduction, food availability and fishing conditions. What is not known is how fishermen follow oceanographic conditions when deciding where to fish? Analyzing changes in satellite surface temperature images in combination with vessel movement dynamics could be able to answer this question and be useful in analyzing fleet movement behavior.

To illustrate this point, primary individual vessel movement data for trawl vessel over 100 tonnes in the East China Sea were extracted from logbooks kept by the Fisheries Radio Station of the Keelung Fisheries Association. The reported fishing locations of the offshore trawl fleets are shown as dots in the SST satellite images presented in Figures 2 to 6, respectively. It is obvious that the scatter diagram of Taiwan trawl 


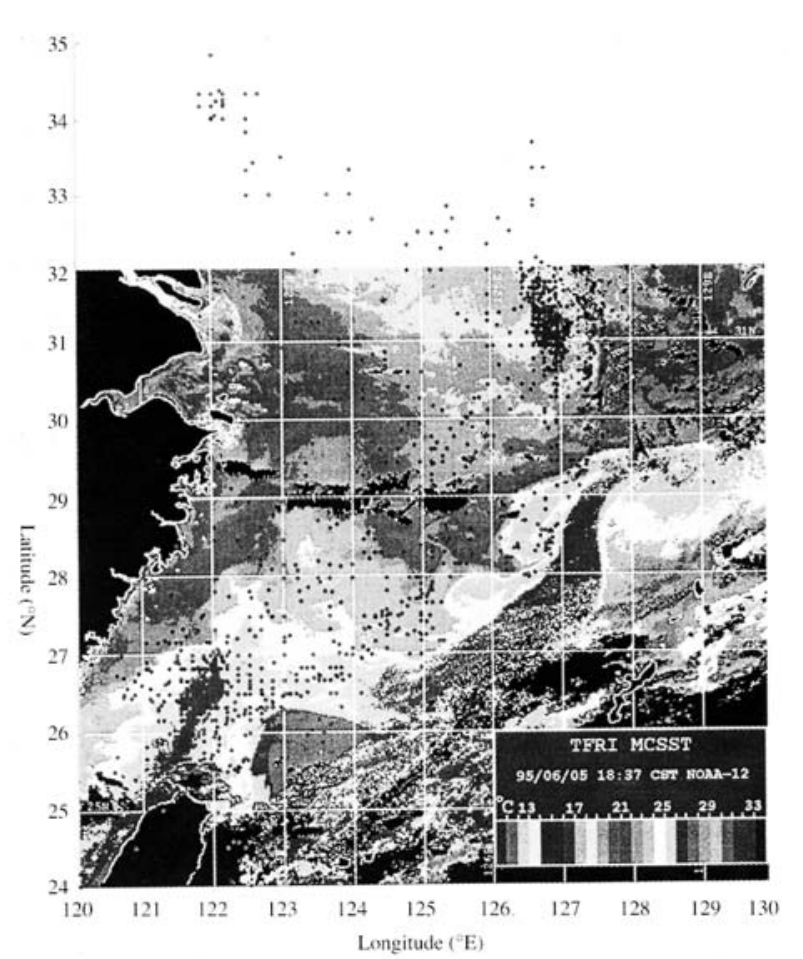

Fig. 5. The scatter diagram of Taiwan trawl vessel movements from May 1 to June 30, 1995 and the NOAA-12 satellite image of sea surface temperature in the East China Sea, June 5, 1995.

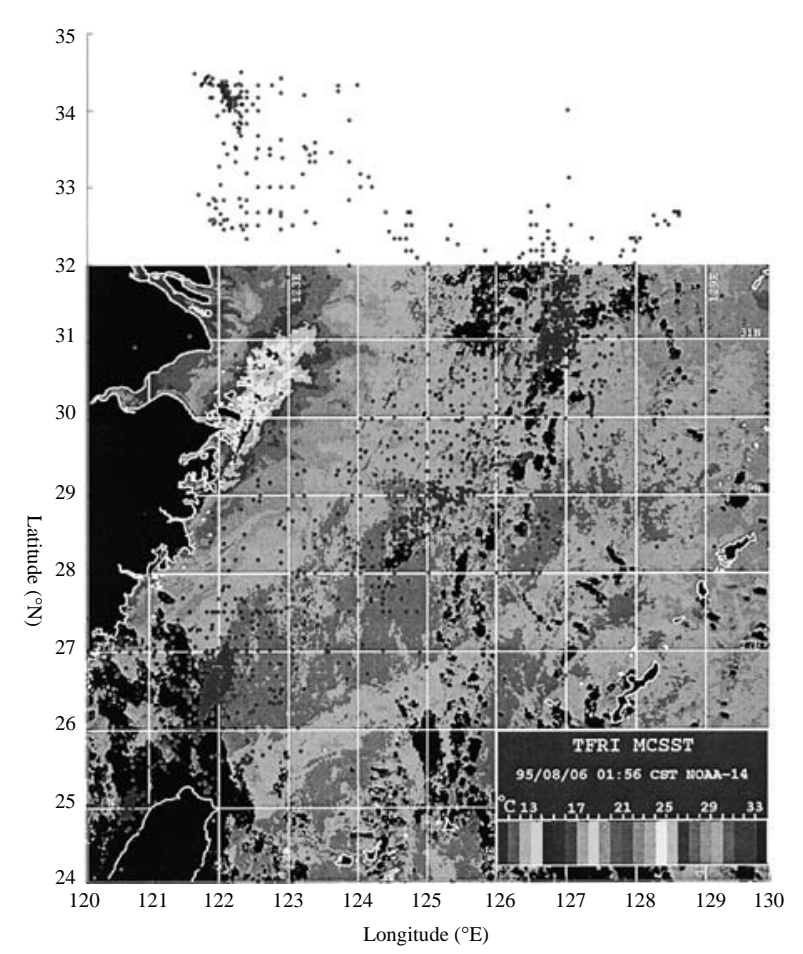

Fig. 6. The scatter diagram of Taiwan trawl vessel movements from July 1 to Aug. 31, 1995 and the NOAA-12 satellite image of sea surface temperature in the East China Sea, Aug. 6, 1995.

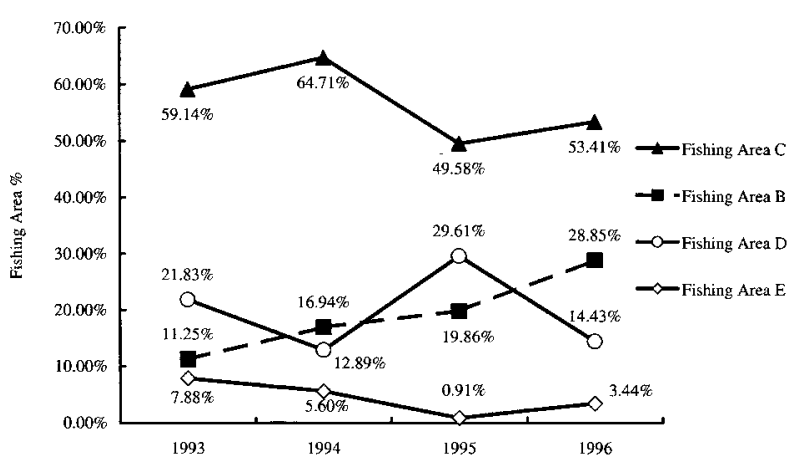

Fig. 7. Average percent of days spent in each fishing area after excluding days spent in area A for 30 representative trawl fishing vessels in the northeastern fishing grounds of Taiwan.

vessel movement dynamics, which are shown in Figures 2 to 6 , respectively, varied across different seasons.

Seasonal SST data are used to identify different seasonal fishing patterns in the East China Sea. Figure 2 represents the autumn fishing season during September to December, when SST ranged from $21^{\circ} \mathrm{C}$ to $26^{\circ} \mathrm{C}$ in most parts of the East China Sea. Notice the belt shaped pattern of the Kuroshio main current which flows into the East China Sea. Figure 3 shows the winter season, which is usually between December and February, when the Kuroshio's northeastwardly flow has a smaller temperature influence and the cold water mass along the Mainland China gradually moves into the Taiwan Strait. Figures 4 and 5 show two SST patterns during the spring season, one from March to April and the other from May to June. During the summer season, which is from July to August, SSTs ranged from $28^{\circ} \mathrm{C}$ to $33^{\circ} \mathrm{C}$ and the water temperature in the East China Sea are high everywhere (Figure 6).

First of all, the reported days spent in fishing locations A, B, C, D, and E from 1993 to 1996 are analyzed according to the logbook entries for each fishing vessel. From all vessels that had about 365 reported days in one year, 30 vessels are randomly selected for this analysis. In this sample of 30 vessels, the percentage of reported days spent in area A in 1993, 1994,1995 , and 1996 was $44.78 \%, 42.79 \%, 35.46 \%$, and $35.89 \%$, respectively. Since days spent in area A include staying at base - Keelung harbor - and also include the trip to and from base to the fishing area, it is necessary to exclude reported days in area A when identifying the relative percentages of actual fishing days in areas B, C, D, and E. Areas B, C, D, and E account for $11.25 \%, 59.14 \%, 21.83 \%$, and $7.88 \%$ of total fishing days in 1993, respectively, when excluding days reported in area A. Figure 7 shows the overall average percentages of fishing days spent in areas B, C, D, and E for 30 representative trawl vessels from 1993 
Table 1. Wilcoxon sign tests of the percent of days spent in each fishing area of the offshore trawl fisheries in the northeastern of Taiwan

\begin{tabular}{|c|c|c|c|c|c|c|c|c|c|c|}
\hline \multirow{2}{*}{$\begin{array}{l}\text { Z } \text { value }^{1} \\
\text { Fishing } \\
\text { Area }\end{array}$} & \multicolumn{4}{|c|}{ I. Hypothesis test of individual fishing vessel vs. the average } & \multicolumn{6}{|c|}{ II. Hypothesis test of individual fishing vessel across different years } \\
\hline & 1993 & 1994 & 1995 & 1996 & $\begin{array}{c}1994 \text { vs. } \\
1993\end{array}$ & $\begin{array}{c}1995 \text { vs. } \\
1993\end{array}$ & $\begin{array}{c}1996 \text { vs. } \\
1993\end{array}$ & $\begin{array}{c}1995 \text { vs. } \\
1994\end{array}$ & $\begin{array}{c}1996 \text { vs. } \\
1994\end{array}$ & $\begin{array}{c}1996 \text { vs. } \\
1995\end{array}$ \\
\hline B & $\begin{array}{c}-1.10 \\
(0.137)\end{array}$ & $\begin{array}{l}-1.10 \\
(0.137)\end{array}$ & $\begin{array}{c}-1.10 \\
(0.137)\end{array}$ & $\begin{array}{c}-0.37 \\
(0.358)\end{array}$ & $\begin{array}{c}1.46 \\
(0.072)\end{array}$ & $\begin{array}{c}1.83^{*} \\
(0.034)\end{array}$ & $\begin{array}{l}3.02 * * \\
(0.001)\end{array}$ & $\begin{array}{c}0.39 \\
(0.347)\end{array}$ & $\begin{array}{l}2.27 * * \\
(0.012)\end{array}$ & $\begin{array}{l}3.16^{* *} \\
(0.001)\end{array}$ \\
\hline $\mathrm{C}$ & $\begin{array}{c}0.00 \\
(0.500)\end{array}$ & $\begin{array}{c}1.10 \\
(0.137)\end{array}$ & $\begin{array}{c}1.10 \\
(0.137)\end{array}$ & $\begin{array}{c}0.37 \\
(0.358)\end{array}$ & $\begin{array}{c}1.46 \\
(0.072)\end{array}$ & $\begin{array}{c}-2.79 * * \\
(0.003)\end{array}$ & $\begin{array}{c}-0.37 \\
(0.358)\end{array}$ & $\begin{array}{c}-4.02 * * \\
(0.000)\end{array}$ & $\begin{array}{c}-2.56^{* *} \\
(0.005)\end{array}$ & $\begin{array}{c}0.56 \\
(0.289)\end{array}$ \\
\hline $\mathrm{D}$ & $\begin{array}{c}-0.73 \\
(0.233)\end{array}$ & $\begin{array}{l}-1.10 \\
(0.137)\end{array}$ & $\begin{array}{c}-0.73 \\
(0.233)\end{array}$ & $\begin{array}{l}-1.83 * \\
(0.034)\end{array}$ & $\begin{array}{l}-1.96 * \\
(0.025)\end{array}$ & $\begin{array}{l}3.02 * * \\
(0.001)\end{array}$ & $\begin{array}{c}-1.00 \\
(0.159)\end{array}$ & $\begin{array}{c}4.041 * * \\
(0.000)\end{array}$ & $\begin{array}{c}1.04 \\
(0.149)\end{array}$ & $\begin{array}{c}-4.04 * * \\
(0.000)\end{array}$ \\
\hline $\mathrm{E}$ & $\begin{array}{c}-1.10 \\
(0.137)\end{array}$ & $\begin{array}{l}-1.83 * \\
(0.034)\end{array}$ & $\begin{array}{c}-3.65^{* *} \\
(0.000)\end{array}$ & $\begin{array}{c}-2.56^{* *} \\
(0.005)\end{array}$ & $\begin{array}{l}-2.56 * * \\
(0.005)\end{array}$ & $\begin{array}{c}-3.96 * * \\
(0.000)\end{array}$ & $\begin{array}{c}-2.71 * * \\
(0.003)\end{array}$ & $\begin{array}{c}-1.60 \\
(0.054)\end{array}$ & $\begin{array}{c}-1.50 \\
(0.067)\end{array}$ & $\begin{array}{c}1.07 \\
(0.143)\end{array}$ \\
\hline
\end{tabular}

${ }^{1} \mathrm{Z}$ value is distributed as standard normal distribution.

${ }^{2}$ Single tail $p$-values in parentheses.

*represents statistically significant under $10 \%$ significance level.

**represents statistically significant under 5\% significance level.

Source: Logbooks of the Trawl Vessels in Keelung, Fisheries Radio Station in Keelung, January 1, 1993 - January 31, 1997.

to 1996 .

Comparing areas $\mathrm{B}, \mathrm{C}, \mathrm{D}$, and $\mathrm{E}$, it is obvious that area $\mathrm{C}$ was the most important and area $\mathrm{E}$ the least important fishing area from 1993 to 1996. This is an important fact in documenting Taiwan's trawl fishing fleet activities in the East China Sea and especially in the "Sino-Japan Co-Management Zone", which was declared by Mainland China and Japan in 1997. The evidence is that Taiwan has historically been fishing in what is now the "Sino-Japan Co-Management Zone" and should therefore be entitled to keep its traditional fishing rights in that area.

\section{HYPOTHESIS TESTING OF THE VARIABILITY OF OFFSHORE TRAWL FLEET MOVEMENT DYNAMICS}

A scatter diagram illustrating the vessel movements for one representative fishing boat from January 1993 to December 1996 is shown in Figure 1. Notice that the northeastern trawl fishing ground is divided into areas A, B, C, D, and E as the results of the density of fleet dynamics of offshore trawl fleet in the East China Sea and also the seasonal satellite thermal images. In the remainder of this paper we will test two hypotheses looking at fishermen's fleet movement behavior, both of which address how fishing location are varying among different fishing areas and years.

Hypothesis Test of the Variability of the Percent of Days Spent in Each Fishing Area by Each Individual Fishing Vessel vs. the Average for the Fleet

In order to investigate if the number of days each fishing vessel spends in a particular area is different from the average number of days spent by the whole fleet in that area, a Wilcoxon sign test is applied. The first four columns of Table 1 show the single population Wilcoxon test statistics. The null hypothesis is defined so that the percent of days spent in each fishing area by each individual vessel is not different from the average for all 30 vessels for that year. The test involves comparisons such as those shown in Table 1. For example, for fishing area $\mathrm{E}$ in 1994, the standardized normal test statistic $Z$ for the difference in the percent of fishing days spent by each representative fishing vessels as compared to the average for all 30 vessels is -1 . 83 , with a single tail $p$-value of 0.034 . This value rejects the null hypothesis that there is no statistically significant difference between how many days each vessel is fishing in area $\mathrm{E}$ at the $10 \%$ significance level. In particular, for three years - 1994, 1995 and 1996 - the percent of days spent by each individual vessel in fishing area $E$ is significantly different from the average at the $10 \%$ significance level. In other words, some vessels spent significantly more time in area $\mathrm{E}$ than did others.

The percent of days spent by each vessel in fishing areas B, C, and D between 1993 and 1996 was not significantly different from the average for the sample. An exception was fishing area D in 1996 where some fishermen spent significantly more time here than did others. Note though that area $\mathrm{E}$ was the least important fishing area and most fishing effort takes place in areas B, C, and D as shown in Figure 7. Our overall conclusion from these data is that for the majority of trawl vessels in the East China Sea, the number of days spent fishing in fishing areas B, C, and D are about the same across all boats. That is to say, vessels do tend to 
distribute themselves among the different areas in various years. This leads one to wonder if the choice of fishing area is based on tradition/experience or if fishermen draw their information about the best fishing grounds from a common source. In short, fishermen's behavior is much like "a school of fish."

\section{Hypothesis Test of the Variability of the Percent of Days Spent in Each Fishing Areas for Each Trawl Vessel across Different Years}

The next test is a paired observation Wilcoxon sign test which identifies if there is a significant difference in the percent of fishing days spent by each trawl vessel in areas B, C, D, and E from year to year. The null hypothesis is that percent of fishing days spent by each vessel in the four areas does not differ statistically between two years. The test involves such comparisons as for example the standardized normal test statistic $\mathrm{Z}$ for the percent of days spent in area $C$ in 1994 to that in 1993. The value of the test statistic in this case is 1.46 (see the $5^{\text {th }}$ column in Table 1 ), with a single tail $p$-value of 0.072 , which indicates that there is no statistically significant difference at the $10 \%$ significance level between 1993 and 1994. In other words, fishing area C was fished in equally as often in 1993 as in 1994 for each individual fishing vessel. However, when comparing the percent of days spent in fishing area $\mathrm{C}$ in 1995 to that in 1993 , the $\mathrm{Z}$ statistic is -2.79 , with a single tail $p$-value of 0.003 , which indicates that fishing days in area $\mathrm{C}$ were significantly fewer in 1995 than in 1993 at the 5\% significance level. In addition, the percent of days in fishing area $\mathrm{C}$ in 1995 is significantly lower than that in 1994. These findings are a strong indication that area C, which was Taiwan's most important fishing area, is not yielding sufficient harvests after 1993 to warrant previous levels of fishing effort, which is leading fishermen to spend less time there and shifting to other areas during 1995 and 1996. This could be the result of stock depletion which appears to be more pronounced in area $\mathrm{C}$ than that in other areas of the East China Sea.

In 1997 Mainland China and Japan declared area C as the "Sino-Japan Co-Management Zone." Could it be that Taiwanese fishermen are not going there as much any more because they don't feel the political protection from Taiwan government since it is now under Japanese and Mainland China control? It is of interest to continue monitoring whether or not the fleet movement dynamics in area $\mathrm{C}$ will be influenced by the "Sino-Japan CoManagement Zone," which was declared by Mainland China and Japan in 1997. Continuing updating database and further research are desirable in the future.

For fishing area $\mathrm{B}$, the percent of fishing days spent here in 1995 and 1996 are both significantly higher than that in 1993. In addition, the percent of days in 1996 is significantly higher than it was in 1994 and 1995. It seems that more and more fishing vessels have switched to fish in area B after 1993. This could be a warning call to Taiwanese government in setting up an effective fishing ground's management policy to sustain the fisheries resources in area B in the near future.

In fishing area D, the percent of days in 1994 is significantly lower than in 1993. In 1995, fishermen have returned to this area and even spent more fishing days then in 1993. However, the percent of days in 1996 dropped to the same level in 1993. This leads one to see that statistical results from Table 1 significantly verified the observed average percent of days in area $D$ as shown in Figure 7.

In fishing area E, the percent of days for 1994, 1995 and 1996 are not significantly different from each other but all significantly lower than that for 1993 .

\section{CONCLUDING REMARKS}

The overall goal of this paper is to provide important information documenting and analyzing Taiwan's trawl fishing fleet activities in the northeastern of Taiwan. Seasonal SST data are used to analyze different seasonal fishing patterns and the density of fleet dynamics of offshore trawl fleet is used to identify five distinct areas (A, B, C, D, and E) in the northeastern of Taiwan. In addition, fishing fleet movement data from 1993 to 1996 are used to examine the variability in the percent of days spent in different fishing areas.

Based on the percent of days spent in each fishing areas (B, C, D, and E) from 1995 to 1996, it is obvious that area $\mathrm{C}$ is the most important fishing area and area $\mathrm{E}$ the least important fishing area to Taiwan's trawl fishing fleet. In particular, the so-called "Sino-Japan CoManagement Zone," which covers most of Taiwan's traditional trawl fishing area C, was declared by Mainland China and Japan in 1997. This study provides important information documenting Taiwan's trawl fishing fleet activities in the East China Sea.

The Wilcoxon sign test results show that the difference in the percent of days spent in fishing areas B, $\mathrm{C}$, and D for each vessel is not statistically significant at the 5\% level, meaning fishermen behave as a group and display similar behavior. Results also show that even though area $\mathrm{C}$ has been the most important fishing area for Taiwan's northeastern trawl fishery, there has been a significant shift by trawl vessels to other areas during 1994 and 1995. Fishing area C may not be yielding sufficient harvests to warrant previous levels of fishing effort. This could be the result of stock depletion which appears to be more pronounced in area $C$ than that in other areas of the East China Sea. 
In contrast, the percent of days spent in fishing area $\mathrm{B}$ shows an increasing trend indicating that this area has become a more important fishing area. However, this could be a warning call to Taiwanese government. It is needed to set up an effective fishing ground's management policy to sustain the fisheries resources in area $B$ in the near future. Fishing area D is also quite important although the percent of days spent here can vary significantly from time to time. Area E remains the least important fishing area and did not experience much difference in the percent of days between 1995 and 1996.

In this paper we have investigated the dynamic behavior of Taiwan's trawl fleet, which is viewed as the fishermen's optimal timing pattern to fish under various oceanographic conditions and also reflects the change of relative resource abundance in various fishing areas and years. The information developed in this study will help trawl fishmen in analying their fishing strategies and provide the government with a document to substantiate its claim over traditional fishing rights in the "Sino-Japan Co-Management Zone."

\section{ACKNOWLEDGEMENT}

The authors thank anonymous reviewers for valuable comments on earlier drafts of this paper. This research was supported in part by the National Science Council (NSC), NSC 86-2415-H-019-003 and the Council of Agriculture (COA), 87-AC-2.2-F-01-3.12, Taiwan, Republic of China. The views expressed in this paper are those of the authors and are not be attributed to NSC or COA.

\section{REFERENCES}

1. Cunningham, Stephen, Michael R. Dunn and David Whitmarsh, Fisheries Economics: An Introduction. Whitstable Litho Ltd., Whitstable, Kent, UK (1985).

2. International Coalition of Fisheries Association, Annual Meeting Report, China Fisheries Association, ed., (1994).

3. Sun, Chin-Hwa, "Optimal Number of Fishing Vessels for Taiwan's Offshore Fisheries - A Comparison of Different Fleet Size Reduction Policies," Marine Resource Economics, 13(4): 275-288 (1998).

4. Chiang, Fu-Sung and Chin-Hwa Sun, "The Application of the Taiwan Fleet Dynamics Management System to Fishing Fleets and Fishery Resources," J. Fish. Soc. Taiwan, 26(2): 103-114 (1999).

5. Wu, Chuan-Chen, "Studies on Shrimp Resources on the North Coast of Taiwan," Bulletin of Taiwan Fisheries Research Institute, No. 32 (1980).

6. Liu, His-Chiang and Chin-Lau Kuo, "Analysis of the
Fisheries Resource for Taiwan Offshore Small Trawl Vessels," Bulletin of Taiwan Fisheries Research Institute, No. 30: 221-280 (1978) (in Chinese).

7. Young, Chun-Te, Yau-Shou Chow, Chao-Ching Chen, and Hsueh-Chien Liao, A Preliminary Study of the Bottom Trawl Fisheries Products in Taiwan Strait," China Fisheries Monthly, 402: 29-80 (1986) (in Chinese).

8. Chow, Yau-Shou, Chao-Ching Chen, and Chan-Shan Huang, "Study on the Escape of Fish through Different Parts of a Bottom Otter Trawl Net," Proceedings of the Second Asian Fisheries Forum, Tokyo, Japan, 17-22 April, (1989).

9. Chow, Yau-Shou and Tsann-Shing Huang, "Observation on the Fish School Passing Through the Opening of Trawl Net," J. Fish. Soc. Taiwan, 17(1): 35-42 (1990).

10. Huang, Tsann-Shing and Yau-Shou Chow, "An Echo Survey on the Behavior of Fish Schools when Entering the Trawl Net," J. Fish. Soc. Taiwan, 18(3): 205-213 (1991).

11. Huang, Tsann-Shing and Yau-Shou Chow, "The Effect of Trawl Codend Design on Selection Characteristics," J. Fish. Soc. Taiwan, 19(2): 103-114 (1992a).

12. Huang, Tsann-Shing and Yau-Shou Chow, "The Study of Fishing Efficiencies of Optimal Mesh on 56mm," J. Fish. Soc. Taiwan, 19(3): 211-221 (1992b).

13. Taiwan Fisheries Research Institute, "NOAA Satellite SST Imageries Database for East China Sea," Remote Sensing Lab., Department of Fisheries Information, http:/ /www.tfrin.gov.tw/D-FI/lab.stars/service/keepsst/index. html (1996).

14. Hilborn, Ray, and Max Ledbetter, "Analysis of British Columbia Salmon Purse-Seine Fleet: Dynamics of Movement," J. Fish. Res. Board Can., 36: 384-91 (1979).

15. Bochstael, N.E. and J.J. Opaluch, "Discrete Modelling of Supply Response under Uncertainty: The Case of the Fishery," J. Envi. Econ. Mana., 10: 125-37 (1983).

16. Hilborn, Ray, "Fleet Dynamics and Individual Variation: Why Some People Catch More Fish than Others," Can. J. Fish. Aquat. Sci., 42:2-13 (1985).

17. Anderson, L.G., "A Management Agency Perspective of the Economics of Regulation," the Proceedings of the Second Conference of the International Institute of Fisheries Economics and Trade, Vol. 1, Corvallis: Oregon State University Sea Grant College Program (1985).

18. Eales, James, and James E. Wilen, "An Examination of Fishing Location Choice in the Pink Shrimp Fishery," $J$. Fish. Res. Board Can., 2(4): 331-50 (1986).

19. Ward, John M., and Jon G. Sutinen, "Vessel Entry-Exit Behavior in the Gulf of Mexico Shrimp Fishery," Amer. J. Agr. Econ., 77: 916-23 (1994).

20. Canavos, G.C., Applied Probability and Statistical Methods, Boston: Little, Brown and Company (1984). 


\title{
臺灣近海拖網漁船船位動態分析一 海水表層水温資料之應用
}

\author{
孫金華江福松
}

國立臺灣海洋大學漁業經濟研究所

\section{摘 要}

本文主要是應用㗌灣沿近海衛星海水表層水温 影像資料和漁船船位資料, 期能完整紀錄及掌握拖網 漁船在不同時點下的動態, 並研究近海拖網漁船在不 同時點和作業漁區的空間選擇行爲, 進而探討拖網漁 民有關動態漁區選擇行爲的趨勢, 研究結果顯示隨著 不同季節海水表水温的改變, 拖網漁船漁掞作業的船 位分佈亦顯著的不同。此外，針對不同漁場別各年間 分配比率之Wilcoxon符號檢定的結果, 可看出漁船 明顯地集中於漁區C, 但1995及1996年作業天數比率 顯著下降, 可能是因爲該區域漁業資源的枯竭速度較 其它區域來的快, 無法滿足漁掞業者維持相同的投入 水準。值得注意的是日本與中國大陸1997年所簽訂 「日中漁業協定」, 劃定䓨灣拖網漁業傳統漁區（漁 區 C）爲暫訂措施水域, 值得未來更新漁船動態資料 庫, 及進一步評估其對台灣拖網漁業的影響程度。 